University of Nebraska - Lincoln

DigitalCommons@University of Nebraska - Lincoln

USDA National Wildlife Research Center - Staff Publications
U.S. Department of Agriculture: Animal and Plant Health Inspection Service

February 2004

\title{
Dispersal characteristics of swift foxes
}

\author{
J.F. Kamler \\ Texas Tech University, Lubbock \\ Warren B. Ballard \\ Texas Tech University, Lubbock \\ Eric M. Gese \\ Utah State University, eric.gese@usu.edu \\ R.L. Harrison \\ University of New Mexico, Albuquerque, NM \\ Seija M. Karki \\ Utah State University, Logan
}

Follow this and additional works at: https://digitalcommons.unl.edu/icwdm_usdanwrc

Part of the Environmental Sciences Commons

Kamler, J.F.; Ballard, Warren B.; Gese, Eric M.; Harrison, R.L.; and Karki, Seija M., "Dispersal characteristics of swift foxes" (2004). USDA National Wildlife Research Center - Staff Publications. 339.

https://digitalcommons.unl.edu/icwdm_usdanwrc/339

This Article is brought to you for free and open access by the U.S. Department of Agriculture: Animal and Plant Health Inspection Service at DigitalCommons@University of Nebraska - Lincoln. It has been accepted for inclusion in USDA National Wildlife Research Center - Staff Publications by an authorized administrator of DigitalCommons@University of Nebraska - Lincoln. 


\title{
Dispersal characteristics of swift foxes
}

\author{
Jan F. Kamler, Warren B. Ballard, Eric M. Gese, Robert L. Harrison, and Seija M. Karki
}

\begin{abstract}
From 1997 to 2001, we monitored movements of 109 adult and 114 juvenile swift foxes, Vulpes velox (Say, 1823), at study sites in Colorado, New Mexico, and Texas to determine patterns of dispersal. Significantly more male (93\%) than female (58\%) juveniles dispersed, and both sexes had similar bimodal dispersal patterns with peaks in September-October and JanuaryFebruary. Adult dispersal occurred more evenly throughout the year, and significantly more male (32\%) than female (5\%) adults dispersed. Adult males tended to disperse after the death of their mate. Of dispersing foxes with known fates, settlement percentages in new territories were similar between juvenile males and females (40\% overall), but they were significantly lower than for adults (89\%). All other dispersing foxes with known fates died. Among juvenile females with known fates, similar percentages of philopatric and dispersing foxes reproduced as yearlings (50\% overall), so the benefits of dispersal versus philopatry were not clear. Although rarely reported for other species, adult males were an important dispersal cohort in swift foxes (43\% of male dispersals and $25 \%$ of all dispersals). Because of the female-biased philopatry among swift foxes, dispersal of adult males likely decreased the chances for inbreeding (e.g., father-daughter breeding).

Résumé : De 1997 à 2001, nous avons suivi les déplacements de 109 adultes et de 114 jeunes du renard véloce, Vulpes velox (Say, 1823), dans des sites d'étude du Colorado, du Nouveau-Mexique et du Texas afin de déterminer leurs patterns de dispersion. Significativement plus de jeunes mâles (93\%) que de jeunes femelles (58 \%) se dispersent; les patterns de dispersion bimodaux, avec des maximums en septembre-octobre et en janvier-février, sont semblables chez les deux sexes. La dispersion des adultes se répartit plus uniformément au cours de l'année et elle implique significativement plus de mâles (32\%) que de femelles (5 $\%$ ). Les adultes mâles ont tendance à se disperser après la mort de leur partenaire. Chez les renards qui se sont dispersés et dont le sort est connu, le pourcentage d'animaux qui se sont établis sur de nouveaux territoires est semblable chez les jeunes mâles et femelles (40\% en tout), mais il est significativement plus faible que chez les adultes ( $89 \%)$. Tous les autres renards qui se sont dispersés et dont le sort est connu sont morts. Chez les jeunes femelles dont le sort est connu, des pourcentages semblables d'animaux philopatriques et dispersés se sont reproduits dès la première année ( $50 \%$ en tout); les bénéfices de la dispersion par rapport à la philopatrie ne sont donc pas évidents. Alors que le phénomène a rarement été signalé chez d'autres espèces, les mâles adultes constituent une importante cohorte de dispersion chez les renards véloces (43\% des dispersions des mâles et $25 \%$ de toutes les dispersions). Puisque la philopatrie chez les renards véloces est surtout l'apanage des femelles, la dispersion des mâles adultes diminue vraisemblablement la probabilité des accouplements consanguins (e.g., accouplements père-fille). [Traduit par la Rédaction]
\end{abstract}

\section{Introduction}

The conservation of swift foxes, Vulpes velox (Say, 1823), is a management concern throughout the western Great Plains of North America because of severe declines in their distribution and numbers (Kahn et al. 1997). Conservation actions include maintaining stable populations, increasing and enhancing low populations, and reintroducing populations into parts of their former range (Scott-Brown et al. 1987; Kahn et al.
1997). Although research on swift foxes has increased recently to help elucidate important aspects of their ecology (Kitchen et al. 1999; Matlack et al. 2000; Olsen and Lindzey 2002; Harrison 2003; Kamler et al. 2003), little information exists concerning characteristics of their dispersal. Dispersal can play an important role in the mating system, genetic structure, population regulation, spatial distribution, and local extinction of many animal populations (Chepko-Sade and Halpin 1987; Thomas 2000; Poethke et al. 2003). Additionally, determining

Received 29 June 2004. Accepted 15 December 2004. Published on the NRC Research Press Web site at http://cjz.nrc.ca on 16 February 2005.

J.F. Kamler1 and W.B. Ballard. ${ }^{2}$ Department of Range, Wildlife, and Fisheries Management, Box 42125, Texas Tech University, Lubbock, TX 79409, USA.

E.M. Gese. U.S. Department of Agriculture, Wildlife Services, National Wildlife Research Center, Department of Forest, Range, and Wildlife Sciences, Utah State University, Logan, UT 84322, USA.

R.L. Harrison. Department of Biology, University of New Mexico, Albuquerque, NM 87131, USA.

S.M. Karki. Department of Forest, Range, and Wildlife Sciences, Utah State University, Logan, UT 84322, USA.

${ }^{1}$ Present address: Wildlife Conservation Research Unit, Oxford University, Tubney House, Abingdon OX13 5QL, UK.

${ }^{2}$ Corresponding author (e-mail: warren.ballard@ttu.edu). 
dispersal patterns of a species can provide important information concerning their evolutionary history, social behavior, stability of population, and recolonization potential (Howard 1960; Roff 1975; Waser 1985).

Among canid species, there is considerable variation in dispersal patterns, philopatry, social organization, and mating systems (Moehlman 1989). Several factors are suggested to contribute to these behavioral variations among canid species, including body size, feeding ecology, and resource availability (Moehlman 1989; Geffen et al. 1996). Concerning dispersal patterns, the common trend among fox species is for juvenile males to disperse, whereas juvenile females remain philopatric (Macdonald 1979; von Shantz 1981, 1984; Moehlman 1989; Koopman et al. 2000). A primary reason for male-biased dispersal in juveniles appears to be inbreeding avoidance (Pusey 1987), although other factors may also be involved (Moore and Ali 1984; Dobson and Jones 1985). Dispersal has several associated costs, such as increased energy demands, difficulty in finding prey in unfamiliar areas, increased exposure to predators, and lack of suitable cover (O'Neal et al. 1987; Koopman et al. 2000). Consequently, it can be beneficial for juvenile females to remain philopatric because they can avoid the high costs of dispersal, and even may acquire experience in raising young, increase inclusive fitness, inherit a portion of the natal territory, and eventually achieve reproductive status (Moehlman 1989). However, juvenile females that remain philopatric might be less likely to breed their first year compared with dispersers, which constitutes a trade-off associated with philopatry (Emlen 1982).

Little is known about dispersal behaviour of swift foxes. In a previous analysis based on swift foxes studied from 1997 to 2001 in Colorado, New Mexico, and Texas, Kamler et al. (2004) determined that breeding males usually dispersed after their mates' deaths, and then often paired with settled females in other territories. In contrast, breeding females usually maintained their territory after their mates' deaths, and then often paired with dispersing males. Furthermore, males abandoned pups after female deaths, whereas females successfully reared pups in the absence of males, indicating swift foxes exhibited a female-based social system (Kamler et al. 2004). The purpose of this paper, then, was to describe the timing of swift fox dispersals, compare dispersal rates among demographic groups, and compare fates of dispersing and philopatric individuals.

\section{Methods}

Data presented here are from three different research teams that conducted separate studies of swift foxes from 1997 to 2001 in southeastern Colorado (E.M.G., S.M.K.), northeastern New Mexico (R.L.H.), and northwestern Texas (J.F.K., W.B.B.). Detailed descriptions of study sites can be found in Kitchen et al. (1999) for Colorado, Harrison (2003) for New Mexico, and Kamler et al. (2003) for Texas. In all studies, swift foxes were captured in boxtraps, equipped with radio collars, and then monitored on a weekly or biweekly basis. Our research and handling protocols were approved by the Institu- tional Animal Care and Use Committees at Texas Tech University (No. 00979BX), University of New Mexico (No. 9811-B), Utah State University (No. 841), and the National Wildlife Research Center (No. QA-472). Swift foxes were aged by tooth wear, body size, and reproductive condition (Rongstad et al. 1989). Foxes were considered juveniles until the breeding season following their birth, whereas all other foxes were considered adults. Female foxes were considered breeders if they were pregnant when captured, or showed evidence of nursing during or after the pup-rearing season (e.g., elongated nipples; Mech et al. 1993). Adult male foxes were considered breeders if they had an established territory and were associated with an adult female (radio-collared or un-radio-collared) during the breeding and pup-rearing periods. Foxes were considered to belong to the same family group if they used the same area and dens concurrently (Kitchen et al. 1999).

Mean seasonal home ranges of swift foxes in Colorado were $<6 \mathrm{~km} 2$ (Karki 2003; sample sizes were not large enough to calculate seasonal home ranges in New Mexico and Texas). Because swift foxes generally have circular home ranges (Kamler 2002), movements $\geq 2 \mathrm{~km}$ from the center of home ranges were classified as dispersal if the individuals did not return to their original home range (Koopman et al. 2000). Of adults that dispersed, all had established territories prior to dispersal. Natal ranges of young encompassed all den locations of parents, and, if parents were unknown, initial capture locations were used as center of natal ranges (Koopman et al. 2000). During the dispersal period, some juvenile foxes exhibited unusual movements (e.g., concentrating activity near boundaries of their home range) before we lost contact with them. We assumed that these foxes dispersed because juveniles were easily captured, though none of these were captured again despite extensive trapping. Dispersal date for each individual was the median between last location within their home range and first location $>2 \mathrm{~km}$ from their home range.

Dispersal percentages were determined for all demographic groups. For dispersed foxes with known fates, settlement percentage was determined for all demographic groups. A dispersed fox was considered settled if it used the same dens within a $6-\mathrm{km}_{2}$ area for $>1$ month. For juvenile females with known fates, breeding percentage was determined for philopatric and dispersing cohorts. A philopatric female was considered a breeder if she was pregnant when later captured, or showed evidence of nursing during or after the pup-rearing season. Dispersing females were considered breeders if they also showed the above signs of pregnancy, or if they established a new territory in another part of the study site and associated with an adult male during the reproductive season. Causes of mortality for dead foxes was determined by necropsy. Tooth-puncture wounds and hemorrhaging were used to identify predator-caused mortality. Dispersal, settlement, and breeding percentages were compared with Yates' corrected $\chi_{2}$ tests (Zar 1996). Comparisons among sites and years could not be made because of the sample size limitation (five study sites in three states), thus we performed analyses under the assumptions that individuals behaved similarly among sites and years. 
Fig. 1. Month of dispersal for juvenile female $(n=31)$, juvenile male $(n=28)$, adult female $(n=3)$, adult male $(n=21)$ swift foxes (Vulpes velox) monitored in Colorado, New Mexico, and Texas from 1997 to 2001.

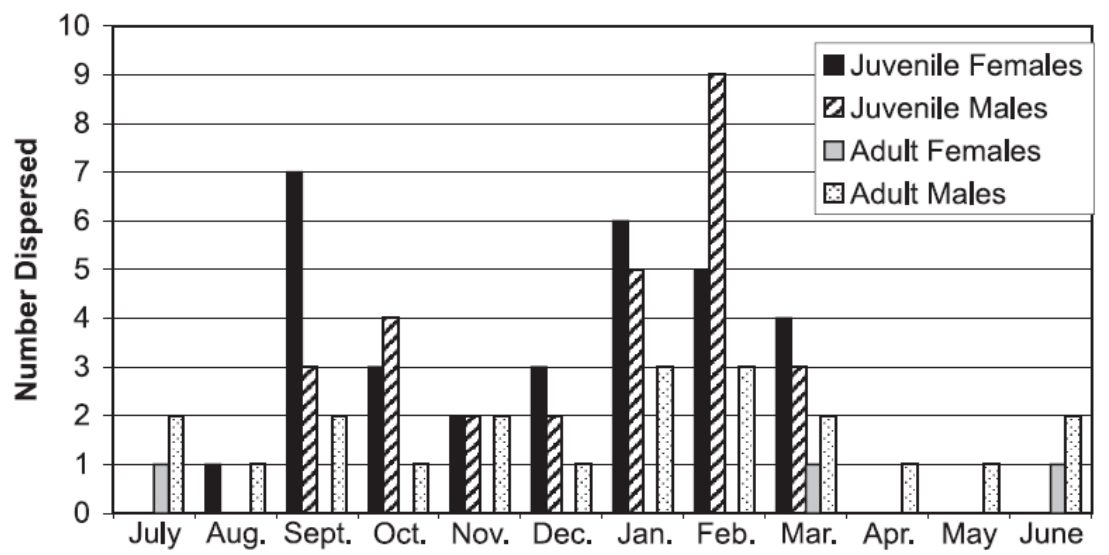

Table 1. Fates of dispersing juvenile and adult swift foxes (Vulpes velox) monitored in Colorado, New Mexico, and Texas from 1997 to 2001.

\begin{tabular}{|c|c|c|c|c|}
\hline & \multirow[b]{2}{*}{$n$} & \multirow[b]{2}{*}{$\begin{array}{l}\text { Number with } \\
\text { unknown fate }(\%)^{*}\end{array}$} & \multicolumn{2}{|l|}{ Known fate } \\
\hline & & & $\begin{array}{l}\text { Number that } \\
\text { settled }(\%)^{\dagger}\end{array}$ & $\begin{array}{l}\text { Number that } \\
\text { died }(\%)^{\dagger}\end{array}$ \\
\hline Juvenile female & 31 & $14(31)$ & $8(47)$ & $9(53)$ \\
\hline Juvenile male & 28 & $15(54)$ & $4(31)$ & $9(69)$ \\
\hline Adult female & 3 & $2(67)$ & $1(100)$ & $0(0)$ \\
\hline Adult male & 21 & $13(62)$ & 7 (88) & $1(13)$ \\
\hline
\end{tabular}

\section{Results}

\section{Juvenile dispersal}

From 1997 to 2001, we radio-collared 126 juvenile (54 males, 72 females) swift foxes in Colorado, New Mexico, and Texas. Twelve juveniles (10 males, 2 females) were excluded from the data set owing to the loss of radio contact (e.g., likely radio-collar failure). Fifty-two percent of juveniles dispersed from their natal range, including $44 \%$ of 70 females and $64 \%$ of 44 males. Because nondispersing foxes that died $<1$ year of age might later have dispersed, we excluded these individuals (17 females, 14 males) from the following statistical comparisons. Among juveniles, a higher percentage of males (93\%) than females $(58 \%)$ dispersed $\left(\chi_{2}=9.68, P=0.002\right)$. Most juveniles dispersed September- October and January-February. Both sexes followed this trend, but juvenile female dispersal peaked in September, whereas juvenile male dispersal peaked in February (Fig. 1).

Dispersing juveniles either died, settled in other parts of the study sites, or dispersed off the study sites and had unknown fates (Table 1). Because juvenile foxes that dispersed off study sites had unknown fates, we excluded these individuals from subsequent analyses. Of dispersing juveniles with known fates, settlement rates were similar $\left(\chi_{2}=0.28, P\right.$ $=0.599)$ between males $(47 \%)$ and females $(31 \%)$. All other dispersing juveniles with known fates died (Table 1).

Of 22 juvenile females that remained philopatric (e.g., did not die or disperse $<1$ year of age), 8 did not reproduce but stayed within their parents' home range as auxiliary adults, 13 reproduced within or adjacent to their natal range, and 1 had an unknown reproductive status. Of the 8 auxiliary females, 2 later died within their natal range, 2 had unknown fates owing to the termination of the study, and the others dispersed the following August $(n=1)$, September $(n=1)$, and October $(n=2)$. Among juvenile females, a similar percentage of philopatric $(62 \%)$ and dispersing $(47 \%)$ foxes reproduced as yearlings $\left(\chi_{2}=0.34, P=0.557\right)$. Two juvenile males remained philopatric but their reproductive status was unknown.

Dispersal of juveniles was generally in a straight direction, with no evidence of transient-like dispersal (Kamler et al. 2000). Dispersal often was abrupt, although predispersal excursions also were observed (Karki 2003). However, not all juveniles that made excursions dispersed. For example, one juvenile female traveled from her natal range twice (in February and March, respectively), once as far as $20 \mathrm{~km}$, before returning to her natal range in early April where she thereafter remained philopatric.

\section{Adult dispersal}

From 1997 to 2001, we radio-collared 125 adult (66 males, 59 females) swift foxes in Colorado, New Mexico, and Texas. A lower percentage of adults (22\%) than juveniles (52\%) dispersed $\left(\chi_{2}=19.83, P<0.001\right)$. Among adults, a higher percentage of males $(32 \%)$ than females $(5 \%)$ dispersed $(P<$ 0.001 ). Adult dispersal occurred in every month of the year, with no apparent peak in dispersal (Fig. 1). Of dispersing males, at least 12 did so after the death of their mate, whereas the mates of the remaining males were not radio-collared (e.g., dispesal after mate's death could not be confirmed). 
Dispersing adults either died, settled on other parts of the study sites, or dispersed off study sites and had unknown fates (Table 1). Adults with unknown fates (e.g., dispersed off study sites) were excluded from subsequent analyses. Of all dispersing swift foxes with known fates, settlement rates were higher $\left(\chi_{2}=4.81, P=0.028\right)$ for adults $(89 \%)$ than juveniles $(40 \%)$.

\section{Mortality}

There were 115 confirmed deaths (70 adults, 45 juveniles) of swift foxes during the study period. Causes of mortality were by coyote (Canis latrans Say, 1823) predation $(n=79)$, unknown $(n=21)$, vehicle collisions $(n=8)$, disease $(n=3)$, human trapping $(n=2)$, and badger (Taxidea taxus (Schreber, $1777)$ ) predation $(n=2)$. Most unknown causes of mortality were probably from coyote predation, thus coyotes accounted for approximately $87 \%$ of swift fox mortalities, followed by vehicle collisions $(7 \%)$, disease $(3 \%)$, human trapping $(2 \%)$, and badger predation $(2 \%)$.

\section{Discussion}

Juvenile swift foxes exhibited female-biased philopatry, similar to that found in other fox species. Previous research showed that there often are trade-offs for philopatry versus dispersal among foxes, especially concerning reproduction and survival. For example, Baker et al. (1998) showed that dispersal, rather than philopatry, was more likely to lead to reproductive status among juvenile red foxes, Vulpes vulpes (L., 1758). However, philopatric juveniles generally have higher survival than dispersing juveniles among red foxes (Harris and Trewhella 1988; Lindstrom 1989; Woollard and Harris 1990) and kit foxes (Vulpes macrotis Merriam, 1888; O’Neal et al. 1987). Dispersal rates for juveniles swift foxes in our study appeared higher than that reported for other fox species. For example, juvenile kit foxes had dispersal rates of $49 \%$ for males and $24 \%$ for females (Koopman et al. 2000). Red fox cubs had dispersal rates of $73 \%$ for males and $32 \%$ for females (Harris and Trewhella 1988). However, dispersal rates among all the above studies were calculated slightly differently, making comparisons difficult. Nevertheless, dispersal rates of foxes can be influenced by a range of demographic and ecological factors (Harris and Trewhella 1988; Lindstrom 1989; Koopman et al. 2000).

Initially, we expected that philopatry would be associated with higher reproduction on our study sites owing to high mortality from coyote predation, as many adult females were killed, allowing juvenile females to obtain breeding status within their natal range. However, the benefits of philopatry versus dispersal among female swift foxes on our study sites were not clear, as both groups of females had similar reproductive success as yearlings. It is possible that we lacked sufficient sample sizes to find differences, as philopatric females tended to have a higher breeding rate. Additionally, because philopatric juvenile females that did not breed usually associated with their parents' next litter, these juvenile females possibly could have benefitted through increased inclusive fitness, as has been suggested for red foxes (Macdonald 1979; von Shantz 1981). Nonbreeding females are common among canid family groups, and have been reported among other fox species, including red foxes (Macdonald 1979; von Shantz 1981, 1984; Baker et al. 1998), kit foxes (O’Neal et al. 1987; Koopman et al. 2000), and arctic foxes (Alopex lagopus (L., 1758); Strand et al. 2000). Regardless, approximately half of all juvenile female swift foxes dispersed, suggesting that there were not large differences in benefits associated with dispersal versus philopatry. Consequently, sexual differences in juvenile dispersal rates were driven by males, as nearly all males that survived to age 1 dispersed, suggesting the dispersal versus philopatry decision was especially important to this sex. Unfortunately, because too few juvenile male foxes remained in natal territories, we could not compare reproductive success between dispersing and philopatric individuals.

Both male and female juveniles exhibited a bimodal dispersal pattern on our study sites, with dispersal peaks in September-October and January-February. The approximate age of juveniles during these two peaks were 6-7 months and 10-11 months of age, respectively. In contrast, previous studies on kit foxes (Koopman et al. 2000) and red foxes (Harris and Trewhella 1988) showed only a single peak in the timing of juvenile dispersal. Reasons for differences in timing of dispersal among fox species are unknown, primarily because the mechanisms triggering dispersal are not well understood among canids.

Bimodal peaks in dispersal were exhibited by juvenile coyotes (Harrison 1992) and young gray wolves (Canis lupus L., 1758; Ballard et al. 1987; Gese and Mech 1991). These dispersal patterns were likely related to increased aggression among litter mates after initial independence, and then increased aggression by adults on juveniles during the breeding season (Gese and Mech 1991; Harrison 1992). The same mechanisms might have affected the timing of swift fox dispersals. The first peak in swift fox dispersal occurred when juveniles were approximately 6-7 months of age, approximately $1-2$ months after they became more independent (e.g., litters separated and pups began using different dens; Karki 2003). Previous research showed that young foxes can be highly aggressive towards each other (White and Harris 1994), and aggression among young canids can result in the emigration of lower ranking individuals (Gese et al. 1996). Alternatively, less social siblings, on their own accord, may be the first to disperse (Bekoff 1977). The second peak in dispersal occurred when juveniles were approximately 10-11 months of age, during pair bonding of breeding adults and just prior to birth of the next litter. Research on red foxes showed that aggression by breeding adults on juveniles increased during pair bonding and near the birthing period (Macdonald 1979; von Shantz 1984), and this often resulted in severe bite wounds on young foxes (White and Harris 1994). Thus, similar to larger canids, timing of juvenile dispersal in swift foxes might have been influenced by periods of increased aggression by both siblings and adults.

Of adults monitored, males (32\%) were more likely to disperse than females $(5 \%)$. Because of the high dispersal percentage of adult males, they were an important dispersal cohort among swift foxes ( $43 \%$ of male dispersals and $25 \%$ of all dispersals). High percentage of adult male dispersal was 
not previously reported among other canid species. The tendency for adult male swift foxes to disperse after the death of their mates (Kamler et al. 2004) might have been beneficial in reducing inbreeding among family members. For example, at least 13 philopatric juvenile females reproduced their first spring, although we found no evidence of adult males breeding with their daughters. After adult female deaths, adult males dispersed regardless if one or more of their daughters remained. Although these dispersal patterns were not reported in other canid species, they should be investigated in other small canids with similar niches as swift foxes.

Because social organization and dispersal patterns within canid species can be influenced by extrinsic factors, such as resource dispersion and food availability (Moehlman 1989; Geffen et al. 1996; Gese et al. 1996; Koopman et al. 2000), dispersal patterns of swift foxes should be investigated in other parts of their range. Our study sites were all located in similar habitat (e.g., short-grass prairie) in the southern portion of the range of swift foxes, thus they might not represent the full range of dispersal patterns exhibited by this species.

\section{Acknowledgments}

Financial and logistical support for research in Colorado was provided by the US Army, Directorate of Environmental Compliance and Management, Fort Carson, Colorado, through the US Fish and Wildlife Service, Colorado Fish and Wildlife Assistance Office, Golden, Colorado, and Utah Cooperative Fish and Wildlife Research Unit, Utah State University, Logan. Additional support was provided by US Department of Agriculture, Wildlife Services, National Wildlife Research Center at Utah State University. Financial and logistical support in New Mexico was provided by New Mexico Department of Game and Fish, and US Fish and Wildlife Service, Ecological Services Field Office, Albuquerque, New Mexico. Financial and logistical support in Texas was provided by Texas Tech University, Texas Parks and Wildlife Department, US Forest Service, and US Department of Agriculture, Wildlife Services. We thank R.L. Gilliland, A.M. Kitchen, P.R. Lemons, K. Mote, C.C. Perchellet, E.R. Schauster, C.G. Schmitt, P.A. Terletzky, and the many field technicians for support and assistance. We also thank B. Sacks and an anonymous reviewer for improvements to the manuscript. This is a Texas Tech University, College of Agricultural Sciences and Natural Resources technical publication T-9-995.

\section{References}

Baker, P.J., Robertson, C.P.J., Funk, S.M., and Harris, S. 1998. Potential fitness benefits of group living in the red fox, Vulpes vulpes. Anim. Behav. 56: 1411-1424.

Ballard, W.B., Whitman, J.S., and Gardner, C.L. 1987. Ecology of an exploited wolf population in southcentral Alaska. Wildl. Monogr. No. 98. pp. 1-54.

Bekoff, M. 1977. Mammalian dispersal and the ontogeny of individual behavioral phenotypes. Am. Nat. 111: 715-732.

Chepko-Sade, B.D., and Halpin, Z.T. (Editors). 1987. Mammalian dispersal patterns: the effects of social structure on population genetics. University of Chicago Press, Chicago.

Dobson, F.S., and Jones, W.T. 1985. Multiple causes of dispersal. Am. Nat. 126: 855-858.

Emlen, S.T. 1982. Cooperative breeding in birds and mammals. In Dispersal and migration. Edited by W.Z. Lidicker and R.L. Caldwell. Hutchinson Ross Publishing Company, Stroudsburg, Pa. pp. 305-339.

Geffen, E., Gompper, M.E., Gittleman, J.L., Luh, H., Macdonald, D.W., and Wayne, R. 1996. Size, life-history traits, and social organization in the Canidae: a reevaluation. Am. Nat. 147: 140 160 .

Gese, E.M., and Mech, L.D. 1991. Dispersal of wolves (Canis lupus) in northeastern Minnesota, 1969-1989. Can. J. Zool. 69: 2946-2955.

Gese, E.M., Ruff, R.L., and Crabtree, R.L. 1996. Social and nutritional factors influencing the dispersal of resident coyotes Anim. Behav. 52: 1025-1043.

Harris, S., and Trewhella, W.J. 1988. An analysis of some of the factors affecting dispersal in an urban fox (Vulpes vulpes) population. J. Appl. Ecol. 25: 409-422.

Harrison, D.J. 1992. Dispersal characteristics of juvenile coyotes in Maine. J. Wildl. Manag. 56: 128-138.

Harrison, R.L. 2003. Swift fox demography, movements, denning, and diet in New Mexico. Southwest. Nat. 48: 261-273.

Howard, W.E. 1960. Innate and environmental dispersal of individual vertebrates. Am. Midl. Nat. 63: 152-161.

Kahn, R.L., Fox, L., Horner, P., Giddings, B., and Roy, C. 1997. Conservation assessment and conservation strategy for swift fox in the United States. South Dakota Department of Game, Fish, and Parks, Pierre.

Kamler, J.F. 2002. Relationships of swift foxes and coyotes in northwest Texas. Ph.D. thesis, Texas Tech University, Lubbock.

Kamler, J.F., Gipson, P.S., and Snyder, T.R. 2000. Dispersal characteristics of young bobcats from northeastern Kansas. Southwest. Nat. 45: 543-546.

Kamler, J.F., Ballard, W.B., Gilliland, R.L., Lemons, P.R., and Mote, K. 2003. Impacts of coyotes on swift foxes in northwestern Texas. J. Wildl. Manag. 67: 317-323.

Kamler, J.F., Ballard, W.B., Gese, E.M., Harrison, R.L., Karki, S., and Mote, K. 2004. Adult male emigration and a female-based social organization in swift foxes, Vulpes velox. Anim. Behav. 67: 699-702.

Karki, S.M. 2003. Effects of coyote removal on swift fox (Vulpes velox) population ecology in southeastern Colorado. M.S. thesis, Utah State University, Logan.

Kitchen, A.M., Gese, E.M., and Schauster, E.R. 1999. Resource partitioning between coyotes and swift foxes: space, time, and diet. Can. J. Zool. 77: 1645-1656.

Koopman, M.E., Cypher, B.L., and Scrivner, J.H. 2000. Dispersal patterns of San Joaquin kit foxes (Vulpes macrotis mutica). J. Mammal. 81: 213-222.

Lindstrom, E. 1989. Food limitation and social regulation in a red fox population. Holarct. Ecol. 12: 70-79.

Macdonald, D.W. 1979. Helpers in fox society. Nature (Lond.), 282: 69-71.

Matlack, R.S., Gipson, P.S., and Kaufman, D.W. 2000. The swift fox in rangeland and cropland in western Kansas: relative abun- 
dance, mortality, and body size. Southwest. Nat. 45: 221-225.

Mech, L.D., Meier, T.J., and Seal, U.S. 1993. Wolf nipple measurements as indices of age and breeding status. Am. Midl. Nat. 129: 266-271.

Moehlman, P.D. 1989. Intraspecific variation in canid social systems. In Carnivore behavior, ecology, and evolution. Vol. 1. Edited by J.L. Gittleman. Cornell University Press, Ithaca, N.Y. pp. 143163.

Moore, J., and Ali, R. 1984. Are dispersal and inbreeding avoidance related? Anim. Behav. 32: 94-112.

Olsen, T.L., and Lindzey, F.G. 2002. Swift fox survival and production in southeastern Wyoming. J. Mammal. 83: 199-206.

O’Neal, G.T., Flinder, J.T., and Clary, W.P. 1987. Behavioral ecology of the Nevada kit fox (Vulpes macrotis nevadensis) on a managed desert rangeland. In Current mammalogy. Edited by H.H. Genoways. Plenum Press, New York. pp. 443-481.

Poethke, H.J., Hovestadt, T., and Mitesser, O. 2003. Local extinction and the evolution of dispersal rates: causes and correlations. Am. Nat. 161: 631-640.

Pusey, A.E. 1987. Sex-biased dispersal and inbreeding avoidance in birds and mammals. Trends Ecol. Evol. 2: 295-299.

Roff, O.A. 1975. Population stability and the evolution of dispersal in a hetergeneous environment. Oecologia (Berl.), 19: 217-237.

Rongstad, O.J., Laurion, T.R., and Anderson, D.E. 1989. Ecology of swift fox on the Pinon Canyon Maneuver Site, Colorado. Final report, Directorate of Engineering and Housing, Fort Carson, Colo.
Scott-Brown, J.M., Herrero, S., and Reynolds, J. 1987. Swift fox. In Wild furbearer management and conservation in North America. Edited by M. Nowak, J.A. Baker, M.E. Obbard, and B. Malloch. Ministry of Natural Resources, Toronto, Ont. pp. 433-441.

Strand, O., Landa, A., Linnell, J.D., Zimmerman, B., and Skogland, T. 2000. Social organization and parental behavior in the arctic fox. J. Mammal. 81: 223-233.

Thomas, C.D. 2000. Dispersal and extinctions in fragmented landscapes. Proc. R. Soc. Lond. B Biol. Sci. 267: 139-145.

von Schantz, T. 1981. Female cooperation, male competition, and dispersal in the red fox Vulpes vulpes. Oikos, 37: 63-68.

von Schantz, T. 1984. 'Nonbreeders' in the red fox Vulpes vulpes: a case of resource surplus. Oikos, 42: 59-65.

Waser, P.M. 1985. Does competition drive dispersal? Ecology, 66: 1170-1175.

White, P.C.L., and Harris, S. 1994. Encounters between red foxes (Vulpes vulpes): implications for territory maintenance, social cohesion and dispersal. J. Anim. Ecol. 63: 315-327.

Woollard, T., and Harris, S. 1990. A behavioural comparison of dispersing and non-dispersing foxes (Vulpes vulpes) and an evaluation of some dispersal hypothesis. J. Anim. Ecol. 59: 709- 722.

Zar, J.H. 1996. Biostatistical analysis. 3rd ed. Prentice-Hall Inc., Upper Saddle River, N.J. 